\title{
ЕФЕКТИ ЕНТЕРОСОРБЦІї ТА ФІЛГРАСТИМУ ПРИ СУБХРОНІЧНІЙ ДОКСОРУБІЦИНОВІЙ ТОКСИЧНОСТІ
}

\section{Тернопільський національний медичний університет імені І. Я. Горбачевського МОз України}

РЕЗЮМЕ. Побічні реакції при проведенні протипухлинної хіміотерапії часто стають причиною переривання лікування.

Мета роботи - дослідити вплив ентеросорбента С2 та препарату гранулоцитарного колонієстимулювального фактора (Г-КСФ) на гематологічні параметри та біохімічні показники функціонування серця, нирок та печінки у щурів на моделі субхронічної доксорубіцинової токсичності.

Матеріал і методи. Субхронічну токсичність моделювали внутрішньочеревним введенням доксорубіцину (DOX) 1 раз на тиждень у дозі 5 мг/кг маси чотирикратно. Для корекції використовували вуглецевий гранульований ентеросорбент С2 та філграстим. На 29 добу після першої ін'єкції DOX вивчали основні гематологічні параметри, активність ферментів КФК-МВ, АлАТ, АсАТ, лужної фосфатази, рівні загального білка, церулоплазміну, креатиніну

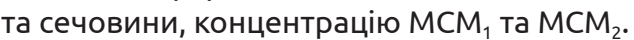

Результати. На тлі субхронічної доксорубіцинової токсичності погіршуються гематологічні параметри досліджуваних щурів, порушуються білково-синтетична функція печінки та показники функціонування нирок, про що свідчить зростання рівнів сечовини та креатиніну на 26,2 \% та 19,2 \%. Усі ці процеси супроводжуються вираженим зростанням маркерів ендогенної інтоксикації: MCM $_{1}$ в 2 рази, MCM $_{2}$ - в 1,75 раза. На кардіотоксичність DOX вказує достовірне зростання активності АСАТ та КФК-МВ - маркерів пошкодження серцевого м'яза (на 75,1 та 64,2 \% відповідно).

Застосування ентеросорбції зменшує побічні ефекти доксорубіцину, що проявляється покращенням гематологічних параметрів, функції нирок, зниженням показників ендогенної інтоксикації. Однак, саме комбінація ентеросорбента С2 з препаратом Г-КСФ демонструє більш суттєве покращення досліджуваних показників, особливо маркерів пошкодження міокарда: знижувалася активність ферментів АсАТ на 26,3%, КФК-МВ - на 17,0 \%; АлАТ на $20,4 \%$.

Висновки. Отримані нами результати слугують основою для подальшого глибшого дослідження можливостей застосування ентеросорбції та Г-КСФ для зменшення побічних реакцій антрациклінових антибіотиків та їх імплементації в клінічну практику.

КЛЮчОВІ СЛОВА: ентеросорбція; доксорубіцин; філграстим; щури.

Вступ. Полікомпонентна високодозова хіміотерапія у поєднанні з хірургічними втручаннями та променевою терапією є важливими факторами успішного лікування пацієнтів зі злоякісними пухлинами в сучасній онкології [1]. Водночас токсичність компонентів хіміотерапії та розвиток побічних реакцій часто є основним фактором переривання та відстрочення цитостатичної терапії, i іноді буває настільки серйозною, що вимагає припинення лікування ще до отримання чіткого протипухлинного ефекту. Частота виникнення різних видів побічних реакцій при проведенні хіміотерапії неоднакова. У 90 \% випадків спостерігається розвиток гастроінтестинальної симптоматики (нудота та блювання, розвиток мукозитів і, як наслідок, транслокація у системний кровообіг грамнегативних кишкових бактерій та їх ендотоксинів тощо), з такою ж частотою розвивається і гематологічна (85-90\%) токсичність у різних її проявах, з яких найнебезпечнішими є фебрильна нейтропенія та інфекційні ускладнення [2-7]. 3 меншою частотою розвиваються тромбоемболічні ускладнення, синдром лізису пухлин, кардіотоксичність, пульмотоксичність, нефротоксичність, гепатоток- сичність, алопеція, різного ступеня негативний вплив на репродуктивну систему, нейротоксичність та інше [8-12]. Серед найчастіших побічних проявів переважають реакції, обумовлені ураженням клітин та тканин з високим темпом проліферації: кровотворних та імунокомпетентних органів, насамперед кісткового мозку, слизової оболонки шлунково-кишкового тракту, волосяних фолікулів, гонад.

Клас антрациклінових антибіотиків, таких як доксорубіцин (DOX), даунорубіцин, епірубіцин та інші, часто використовують у онкологічній практиці, в тому числі в педіатричній, завдяки їх високій протипухлинній активності [3, 13-15]. За умови виявлення захворювання на ранніх стадіях та при застосуванні схем поліхіміотерапії, які базуються на антрациклінах, показник п'ятирічного виживання пацієнтів досягає 80 \% [16]. Основні побічні ефекти, які розвиваються при застосуванні препаратів цієї фармакологічної групи, типові для більшості антинеопластичних лікарських засобів. Характерною ж особливістю DOX та інших антрациклінів $€$ те, що вони здатні пошкоджувати серцевий м'яз. Розвиток дозозалежної карідоток- 
Огляди літератури, оригінальні дослідження, погляд на проблему, випадок з практики, короткі повідомлення сичності $є$ найсуттєвішим фактором, який лімітує застосування цієї групи препаратів [17-21]. Клінічно вирізняють гостру та хронічну кардіотоксичність [22-25]. Гостра форма розвивається в момент введення препарату або через кілька годин після цього. Проявляється переважно транзиторними аритміями та гіпотензією, які, як правило, добре піддаються лікуванню. Хронічна кардіотоксичність проявляється розвитком застійної серцевої недостатності, яка рефрактерна до стандартних інотропних засобів $[13,26]$. Деякі автори виділяють хронічну ранню (проявляється протягом першого року) та пізню, або відстрочену, форми (розвивається протягом від одного до тридцяти років після застосування антрациклінових антибіотиків для лікування онкопатології з піком на 7-10 роках) [27, 28]. Creutzig et al. (2007) відмічають, що частіше хронічна кардіотоксичність розвивається в тих дітей, які перенесли її гостру форму, а також отримували повторні курси лікування антрациклінами, навіть якщо застосовувалися препарати з меншим потенціалом ураження серцевого м'яза [29]. Хронічна доксорубіцинова кардіотоксичність може призводити до розвитку фатальної дилатаційної кардіоміопатії (ДКМП), яка в разі розвитку серцевої недостатності закінчується летально у приблизно 60 \% пацієнтів [11, 21, $30,31]$.

Сьогодні доведений позитивний ефект застосування сорбційної терапії на фоні тривалого застосування токсичних лікарських засобів (при лікуванні туберкульозу, ВІЛ-інфекції тощо) [32, 33], при хронічних запальних процесах з інтоксикацією [34-36], при інфекційних хворобах [37], алергічних захворюваннях [38]. Описані позитивні клінічні ефекти застосування вуглецевого сорбента СУМС-1 при онкопатології, що дозволило знизити дози застосовуваних анальгетиків та зменшити прояви мієлотоксичності й рівень ендогенної інтоксикації [39]. Гранульований вуглецевий ентеросорбент СКН приводив до зменшення токсичності рубоміцину у щурів з перевивними пухлинами, та помірного лейкостимулювального ефекту у пацієнтів, які отримували протипухлинну хіміотерапію $[40,41]$. Відомо, що вуглецеві ентеросорбенти, зокрема Карболайн, мають виражену антиеметогенну дію на фоні застосування різних схем протипухлинної поліхіміотерапії [42, 43]. У хворих з резектабельним раком прямої кишки застосування ентеросорбції знизило частоту розвитку побічних ефектів лікування з 7,4 до 2,9 \%, та дозволило домогтися підвищення загального п'ятирічного виживання пацієнтів 366,1 до 79,3 \% [44]. У пацієнтів з ДКМП та цукровим діабетом після проведення сеансів імуноадсорбції відмічено зниження рівня маркера NT-ргоBNP та

підвищення фракції викиду лівого шлуночка 3 25,5 до 30,9 \% ( $=0,02)$ [45].

Враховуючи вищесказане, а також те, що у порівнянні з рештою популяції у людей з виживанням більше п'яти років після лікування злоякісної патології із застосуванням антрациклінів, ризик смертності, яка безпосередньо пов'язана з серцевою патологією, зростає у 10 разів [46]; а близько 60 \% пацієнтів, які вижили після дитячої онкопатології, отримували препарати саме цієї групи [47, 48], пошук ефективних методів профілактики та пом'якшення кардіотоксичності препаратів вказаної групи вкрай актуальний.

Мета дослідження - вивчити вплив ентеральної сорбційної терапії з ентеросорбентом С2 та препарату гранулоцитарного колонієстимулювального фактора (Г-КСФ) на гематологічні параметри та біохімічні показники функціонування серцевого м'яза, нирок та печінки у щурів на моделі субхронічної токсичності доксорубіцину.

Матеріал і методи дослідження. Дослідження проводили на нелінійних щурах-самцях масою тіла $(200 \pm 20)$ г, яких утримували на стандартному раціоні віварію ТНМУ з доступом ad libitum до питної води. Тварин шляхом сліпої вибірки було рандомізовано у наступні групи $(n=10): 1$. Контрольна група - здорові щури; 2. Група тварин, які отримували доксорубіцин (DOX); 3. Тварини, які з метою корекції отримували ентеральну сорбційну терапію з гранульованим вуглецевим ентеросорбентом C2 (DOX+C2); 4. Тварини, які для корекції отримували ентеральну сорбційну терапію та препаратГ-КСФфілграстим(DOX+C2+філграстим).

Усі маніпуляції проводили відповідно до принципів біоетики Європейської конвенції щодо захисту хребетних тварин, яких використовують в експериментальних та інших наукових цілях (European convention for the protection of vertebrate animals used for experimental and other scientific purposes, Страсбург, 1986) та Директиви Європейського Союзу 2010/10/63 EU щодо експериментів на тваринах.

Субхронічну токсичність доксорубіцину моделювали шляхом введення препарату (Doxorubicin Teva $10 \mathrm{mg} / 5 \mathrm{ml}$, TEVA Pharmachemie, the Netherlands) внутрішньочеревно 1 раз на тиждень 3 розрахунку 5 мг/кг маси щура чотирикратно (сумарна доза 20 мг/кг маси тіла) [49]. Тварини контрольної групи отримували інтраперитонеально еквівалентну кількість стерильного ізотонічного фізрозчину.

Вуглецевий гранульований ентеросорбент

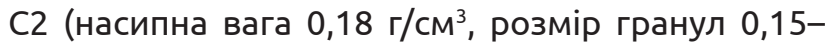

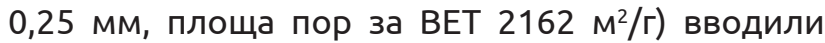
внутрішньошлунково у вигляді зависі в дистильованій воді за допомогою зонда, починаючи з на- 
Огляди літератури, оригінальні дослідження, погляд на проблему, випадок з практики, короткі повідомлення ступного дня після ін'єкції доксорубіцину з розрахунку 5 мл на 1000 г маси щура, що складало 900 мг/кг сухої ваги. Інтактні тварини отримували еквівалентну кількість дистильованої води. Філграстим - офіцинальний препарат гранулоцитарного колонієстимулювального фактора (Нейпоген, F. Hoffmann-La Roche Ltd.), вводили підшкірно з розрахунку 50 мкг/Кг, починаючи з наступного дня після четвертої ін'єкції доксорубіцину впродовж 4 днів один раз на добу.

На 29 добу після першої ін'єкції доксорубіцину тварин під загальним знеболюванням тіопенталом натрію виводили з експерименту. Для досліджень брали цільну кров та сироватку крові. Проводили визначення основних гематологічних параметрів - вмісту лейкоцитів, еритроцитів, тромбоцитів та рівня гемоглобіну - за допомогою автоматичного гемоаналізатора BC-3000Plus Mindray (Mindray, Китай). У сироватці крові визначали активність АлАТ, АсАТ, лужної фосфатази, рівень загального білка, церулоплазміну, рівні креатиніну та сечовини за допомогою стандартних наборів реактивів «Lachema». Визначення вмісту загального білірубіну проводили використовуючи

стандартний набір реактивів «Human». Для вивчення змін активності КФК-МВ використали набip Liquick Cor-CK-MB (Cormay, Польща). Визначення вмісту молекул середньої маси проводили за методикою $[50,51]$, концентрацію MCM $_{1}$ та MCM $_{2}$ у сироватці крові виражали в ум. од./л.

Отриманий цифровий матеріал обробляли методом варіаційної статистики з використанням непараметричних критеріїв та однофакторного дисперсійного аналізу (ANOVA). Для перевірки нормальності вибірок використовували критерій Шапіро-уїлка. Дані вказані як середні арифметичні величини (М) та похибки середніх арифметичних (SE). Зміни вважали достовірними при $p<0,05$. У рисунках та таблицях рівень значимості вказували тільки для достовірних результатів. Для розрахунків використовували комп'ютерну програму StatSoft STATISTICA 10.

Результати й обговорення. Внутрішньочеревне введення доксорубіцину у сумарній дозі 20 мг/кг спричиняло достовірне зниження чисельності лейкоцитів - на 26,4\%, еритроцитів - на 26,2\%, рівня гемоглобіну - на 12,6\%, спостерігалася тенденція до зниження рівня тромбоцитів (табл. 1).

Таблиця 1. Показники периферійної крові щурів на моделі субхронічної доксорубіцинової токсичності та за умов її корекції ентеросорбентом С2 і препаратом гранулоцитарного колонієстимулювального фактора філграстимом

\begin{tabular}{|l|c|c|c|c|}
\hline \multirow{2}{*}{\multicolumn{1}{|c|}{ Група }} & \multicolumn{4}{|c|}{ Показник } \\
\cline { 2 - 5 } & контрольна група & DOX & DOX + C2 & DOX + філграстим + C2 \\
\hline Лейкоцити, 109/л & $5,55 \pm 0,33$ & $4,08 \pm 0,22^{*}$ & $4,60 \pm 0,60$ & $5,68 \pm 0,60 * *$ \\
\hline Еритроцити, 1012/л & $6,92 \pm 0,19$ & $5,11 \pm 0,64^{*}$ & $5,86 \pm 0,70$ & $5,89 \pm 0,71 * *$ \\
\hline Гемоглобін, г/л & $131,83 \pm 4,93$ & $115,29 \pm 3,88^{*}$ & $120,29 \pm 3,91$ & $126,86 \pm 3,45$ \\
\hline Тромбоцити, $10^{9} / л$ & $621,17 \pm 54,65$ & $534,86 \pm 50,13$ & $555,29 \pm 94,72$ & $580,0 \pm 76,23$ \\
\hline
\end{tabular}

Примітка. Достовірність р<0,05 відносно: *-інтактних тварин; ** - групи тварин, які отримували доксорубіцин.

У групі тварин, які отримували ентеросорбент на тлі введення доксорубіцину, усі досліджувані показники мали тенденцію до зростання. Однак достовірно показники змінювалися лише у щурів, яким додатково вводили філграстим. Так, рівень лейкоцитів навіть дещо перевищував вихідний і зростав на 39,2 \%; вміст еритроцитів був вищим на 15,3 \%, порівняно з групою DOX, а чисельність тромбоцитів та рівень гемоглобіну у групі DOX+C2+філграстим наближалася до показників контрольної групи. Усі показники достовірно не відрізнялися від групи DOX+C2.

До ранніх маркерів пошкодження міокарда відносять показник активності КФК-МВ, до пізніх АсАТ. На тлі застосування доксорубіцину спостерігалося достовірне зростання активності АсАТ та КФК-МВ на 75,1 та 64,2 \% відповідно, що свідчить про ушкодження серцевого м'яза. Активність АлАТ зро- стала на 34,5 \%. Рівень лужної фосфатази та рівень загального білірубіну не змінювалися (табл. 2).

Порушувалася білково-синтетична функція печінки, про що свідчить падіння рівня загального білка на 34,9 \%. На тлі порушення серцевої функції на тлі застійних явищ порушується функція не лише печінки, а й нирок (так званий кардіоренальний синдром при серцевій недостатності). Про це свідчить зростання вмісту сечовини та креатиніну на 26,2 та 19,2 \% відповідно, порівняно з тваринами контрольної групи (табл. 3). Усі ці процеси супроводжувалися достовірним зростанням маркерів ендогенної інтоксикації MCM $_{1}$ в 2 рази, МСM $_{2}$ - в 1,75 раза.

Застосування ентеральної сорбційної терапії пом'якшувало прояви функціональної неспроможності серця, печінки та нирок. Так, активність ферментів АсАТ, КФК-МВ та АлАТ знижувалася на 
Огляди літератури, оригінальні дослідження, погляд на проблему, випадок з практики, короткі повідомлення Таблиця 2. Біохімічні показники периферійної крові щурів на моделі субхронічної доксорубіцинової токсичності та за умов їі корекції ентеросорбентом С2 та препаратом гранулоцитарного колонієстимулювального фактора філграстимом, M $\pm S E, n=10$

\begin{tabular}{|l|c|c|c|c|}
\hline \multirow{2}{*}{ Група } & \multicolumn{3}{|c|}{ Показник } \\
\cline { 2 - 5 } & контрольна група & DOX & DOX + C2 & $\begin{array}{c}\text { DOX+ філграстим + } \\
\text { C2 }\end{array}$ \\
\hline $\begin{array}{l}\text { AсAT, } \\
\text { Од/л }\end{array}$ & $134,82 \pm 4,24$ & $236,13 \pm 16,44^{*}$ & $183,68 \pm 14,84^{*}, * *$ & $174,02 \pm 8,88^{*}, * *$ \\
\hline $\begin{array}{l}\text { АлАТ, } \\
\text { Од/л }\end{array}$ & $37,3 \pm 3,40$ & $50,18 \pm 2,88^{*}$ & $42,24 \pm 4,21$ & $39,93 \pm 2,74 * *$ \\
\hline КФК-МВ, УО/л & $80,51 \pm 3,88$ & $121.23 \pm 5.09 *$ & $105,2 \pm 3.72 * *$ & $100,6 \pm 2,97 * *$ \\
\hline $\begin{array}{l}\text { Лужна фосфатаза, } \\
\text { ммоль/л/год }\end{array}$ & $244,24 \pm 10,96$ & $263,92 \pm 13,71$ & $227,46 \pm 17,68$ & $240,77 \pm 16,11$ \\
\hline $\begin{array}{l}\text { Загальний білірубін, } \\
\text { мкмоль/л }\end{array}$ & $4,28 \pm 0,48$ & $4,42 \pm 0,57$ & $4,17 \pm 0,28$ & $4,15 \pm 0,59$ \\
\hline Загальний білок, г/л & $65,01 \pm 2,27$ & $42,32 \pm 5,05^{*}$ & $55,07 \pm 3,11 * *$ & $56,6 \pm 3,20 * *$ \\
\hline
\end{tabular}

Примітка. Достовірність р<0,05 відносно: *-інтактних тварин; ** - групи тварин, які отримували доксорубіцин.

Таблиця 3. Показники сироватки крові піддослідних тварин, $\mathrm{M} \pm \mathrm{SE}, \mathrm{n}=10$

\begin{tabular}{|l|c|c|c|c|}
\hline \multirow{2}{*}{\multicolumn{1}{|c|}{ Група }} & \multicolumn{3}{|c|}{ Показник } \\
\cline { 2 - 5 } & контрольна група & DOX & DOX + C2 & $\begin{array}{c}\text { DOX + філграстим + } \\
\text { C2 }\end{array}$ \\
\hline $\begin{array}{l}\text { Сечовина, } \\
\text { ммоль/л }\end{array}$ & $6,7 \pm 0,52$ & $8,45 \pm 0,43^{*}$ & $7,02 \pm 0,29 * *$ & $6,8 \pm 0,37 * *$ \\
\hline Креатинін, мкмоль/л & $76,51 \pm 3,44$ & $91,23 \pm 4,59 *$ & $78,2 \pm 3,51 * *$ & $78,6 \pm 3,08 * *$ \\
\hline МСМ $_{1}$ ум. од./л & $0,339 \pm 0,050$ & $0,685 \pm 0,060^{*}$ & $0,465 \pm 0,043^{*}, * *$ & $0,445 \pm 0,032^{*}, * *$ \\
\hline МСМ $_{2}$ ум. од./л & $0,456 \pm 0,042$ & $0,799 \pm 0,053^{*}$ & $0,580 \pm 0,040^{*}, * *$ & $0,534 \pm 0,036^{* *}$ \\
\hline
\end{tabular}

Примітка. Достовірність р<0,05 відносно: *- інтактних тварин; ** - групи тварин, які отримували доксорубіцин.

22,2; 13,2 та 15,8 \% відповідно, порівняно з тваринами контрольної групи. Рівень загального білка зростав на 30,1 \%. Вміст креатиніну та сечовини був меншим на 16,9 та $14,2 \%$, водночас рівні $\mathrm{MCM}_{1}$ та MCM $_{2}$ знижувався на 32,1 та 27,4 \% відповідно у групі DOX+C2, порівняно з тваринами, які не отримували чинників корекції.

Показники тварин групи DOX+C2+філграстим також достовірно відрізнялися від щурів групи DOX: знижувалася активність ферментів AcAT (на 26,3 \%), КФК-МВ (на 17,0 \%) та АлАТ (на 20,4 \%). Рівень загального білка зростав на 33,7 \%. Вміст креатиніну та сечовини був меншим на 19,6 та 13,8 \%, водночас рівні МCM $_{1}$ та MCM $_{2}$ знижувалися на 35,0 та 33,2 \% відповідно у групі DOX+C2+ філграстим, порівняно з тваринами, які не отримували чинників корекції.

Комбіноване застосування обох чинників демонструвало чітку тенденцію до покращення усіх досліджуваних показників, що свідчить про переваги комбінації, порівняно із монозастосуванням ентеральної сорбції.

Ретроспективний аналіз чотирьох великих рандомізованих досліджень, які вивчали віддалені результати ад'ювантної ХT у пацієнтів з операбельним раком молочної залози (медіана спостережень 25-28 років), показав, що виживання пацієнтів, які отримали близько 85 \% від запланованої дози, складало 40 \%. Якщо ж отримана доза була в межах 65-85 \%, цей показник складав лише $21 \%$, а у пацієнтів, які отримали менше 65 \% запланованої дози ХT, безрецидивне та загальне виживання не відрізнялося від групи нелікованих хворих [52]. Як відомо, на розвиток ускладнень при проведенні хіміотерапії впливають загальний стан хворого, вік, стать, наявність супутньої патології, попереднє лікування, супутня променева терапія, кількість пройдених курсів хіміотерапії, механізм дії хіміопрепарату та його доза. Комбінація понад двох протипухлинних лікарських засобів обумовлює ширший спектр та вищий ступінь ускладнень, що у певних випадках вимагає зміни дози цитостатиків та призначення супутньої симптоматичної терапії ускладнень [53-56].

На сьогодні найбільш ґрунтовно розроблені стратегії, клінічні підходи та методичні рекомендації до менеджменту побічних ефектів з боку системи крові. Щодо інших побічних ефектів хіміо- 
Огляди літератури, оригінальні дослідження, погляд на проблему, випадок з практики, короткі повідомлення терапії, таких як ураження шлунково-кишкового тракту, гонадотоксичність, нейротоксичність, гепатотоксичність, тривають інтенсивні пошуки можливих шляхів, методів та фармакотерапії для їх попередження і лікування. При виникненні цих ускладнень найчастіше проводиться симптоматична терапія згідно з загальноприйнятими стандартами та протоколами. Такий підхід пов'язаний з відсутністю на фармацевтичному ринку універсальних коректорів токсичної дії цитостатиків, що здатні захищати здорові клітини та підвищувати ефективність і безпечність терапії цитостатиками. Тому до уваги береться ступінь ураження органів-мішеней, систем органів і тяжкість певних симптомів.

Ентеросорбенти, за своєю суттю, - це біоматеріали, що «працюють» у просвіті шлунковокишкового тракту і мають лише локальну фармакокінетику. Однак, власне, завдяки сорбційній детоксикації організму вони діють не лише локально, а й мають дистанційні віддалені ефекти [57-59]. Як відомо, біотрансформація ксенобіотиків у організмі здійснюється у два етапи: 1 - за участю монооксигеназних системендоплазматичного ретикулуму, який є частиною мікросомальної ферментної системи, системи цитохрому Р450; 2 - зв'язування з глюкуроновою кислотою. Далі відбуваються процеси екскреції. Основні задіяні органи і системи - печінка, нирки, ШКТ. Тому завдяки сорбції токсичних метаболітів та сполук ми розвантажуємо основні органи метаболізму та екскреції. Саме цим можна пояснити позитивний ефект ентеросорбента С2 при субхронічній доксорубіциновій токсичності та покращення показників функціонування печінки, нирок, зниження рівня маркерів ураження серцевого м'яза. Ймовірно саме зниження токсичних впливів на кістковий мозок забезпечує зростання основних гематологічних показників та сприяє відновленню і посиленню регенераційних процесів.

Висновки. 1. На тлі субхронічної доксорубіцинової токсичності погіршуються гематологічні по-

\section{ЛІТЕРАТУРА}

1. Можливості удосконалення терапії супроводу при цитостатичному лікуванні пухлин / І. М. Бондаренко, В. Ф. Завізіон, М. В. Артеменко [та ін.] // Медичні перспективи. - 2012. - № 4. - С. 48-53.

2. Бруслова К. М. Застосування препарату теваграстим у дітей з гострими лейкеміями / К. М. Бруслова // Онкологія. - 2013. - Т. 15, № 1. - С. 51-54.

3. Баранова О. Ю. Возможности современной терапии острых нелимфобластных лейкозов взрослых / О. Ю. Баранова, М. А. Волкова // Русский медицинский журнал. Онкология. - 2001. - Т. 9, № 22. - С. 999-1003.

казники досліджуваних тварин (знижується рівень лейкоцитів на 26,4 \%, еритроцитів - на $26,2 \%$, гемоглобіну - на $12,6 \%$, спостерігається тенденція до зниження рівня тромбоцитів). При цьому порушуються білково-синтетична функція печінки (рівень загального білка падає на 34,9 \%, активність АлАт зростає на 34,5 \%) та показники ефективності роботи нирок, про що свідчить зростання вмісту сечовини та креатиніну на 26,2 та на 19,2 \% відповідно, у порівнянні з тваринами контрольної групи. Всі ці процеси супроводжувалися достовірним вираженим зростанням маркерів ендогенної інтоксикації МCM $_{1}$ в 2 рази, MCM $_{2}-$ в 1,75 раза. Про кардіотоксичні прояви застосування доксорубіцину свідчить достовірне зростання активності АсАТ та КФК-МВ, які $\epsilon$ маркерами ушкодження серцевого м'яза - на 75,1 та $64,2 \%$ відповідно.

Застосування ентеральної сорбційної терапії пом'якшує побічні ефекти при субхронічній доксорубіциновій токсичності, що проявляється покращенням гематологічних параметрів, функції нирок (нормалізувалися рівні креатиніну та сечовини), зниженнямпоказниківендогенноїінтоксикації. Однак, саме комбінація ентеросорбента С2 з препаратом Г-КСФ демонструє більш суттєве покращення досліджуваних показників, а особливо маркерів ушкодження міокарда: знижувалася активність ферментів АсАТ на 26,3\%, КФК-МВ - на $17,0 \%$; та АлАТ - на 20,4 \%.

Перспективи подальших досліджень. Отримані нами результати слугують підґрунтям для подальшого поглибленого вивчення можливостей застосування ентеральної сорбційної терапії $з$ вуглецевим гранульованим ентеросорбентом С2 (насипна вага 0,18 г/см³, розмір гранул 0,15-0,25

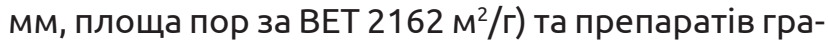
нулоцитарного колонієстимулювального фактора для зменшення побічних реакцій при застосуванні антрациклінових антибіотиків та їх впровадження у клінічну практику.

4. Lyman G. H. Risk factors for febrile neutropenia among patients with cancer receiving chemotherapy: A systematic review / G. H. Lyman, E. Abella, R. Pettengell // Critical Reviews in Oncology/Hematology. - 2014. - Vol. 90, No. 3. - P. 190-199.

5. Liu W. Prognostic value of chemotherapy-induced leukopenia in small-cell lung cancer / W. Liu, C.-C. Zhang, K. Li // Cancer Biology \& Medicine. - 2013. - Vol. 10, No. 2. P. 92-98.

6. Parkhill A. L. Oral mucositis and stomatitis associated with conventional and targeted anticancer therapy / 
Огляди літератури, оригінальні дослідження, погляд на проблему, випадок з практики, короткі повідомлення A. L. Parkhill // Journal of Pharmacovigilance. - 2013. Vol. 01, No. 03.

7. Oral mucositis induced by anticancer therapies / S. Al-Ansari, J. A. E. M. Zecha, A. Barasch [et al.] // Current Oral Health Reports. - 2015. - Vol. 2, No. 4. - P. 202-211.

8. Stensvold E. Fertility-preserving measures for girls and young women with cancer / E. Stensvold, H. Magelssen, I. C. Oskam // Tidsskrift for den Norske lægeforening: tidsskrift for praktisk medicin, ny række. - 2011. - Vol. 131, No. 15. - P. 1429-1432.

9. Diamond O. M. Minimizing the doxorubicin-induced gonadotoxicity by sphingosine-1-phosphate analogue FTY720 / O. M. Diamond, O. Turgeman, Z. Blumenfeld // Am. J. Clin. Exp. Obstet. Gynecol. - 2015. - Vol. 2, No. 1. P. 24-33.

10. Methods of cryopreservation of testicular tissue with viable spermatogonia in pre-pubertal boys undergoing gonadotoxic cancer treatment / V. Keros, K. Hultenby, B. Borgstrom [et al.] // Human Reproduction. - 2007. Vol. 22, No. 5. - P. 1384-1395.

11. Cardio-oncology: a new and developing sector of research and therapy in the field of cardiology / P. M. Kostakou, N. T. Kouris, V. S. Kostopoulos [et al.] // Heart Failure Reviews. - 2019. - No. 1. - P. 91-100.

12. Dose delays, dose reductions, and relative dose intensity in patients with cancer who received adjuvant or neoadjuvant chemotherapy in community oncology practices / N. Denduluri, D. A. Patt, Y. Wang [et al.] // JNCCN Journal of the National Comprehensive Cancer Network. 2015. - Vol. 13, No. 11. - P. 1383-1393.

13. Anthracyclines: molecular advances and pharmacologic developments in antitumor activity and cardiotoxicity / G. Minotti, P. Menna, E. Salvatorelli [et al.] // Pharmacological Reviews. - 2004. - Vol. 56, No. 2. - P. 185-229.

14. Treatment including anthracyclines versus treatment not including anthracyclines for childhood cancer / E. C. van Dalen, M. F. Raphaël, H. N. Caron [et al.] // Cochrane Database of Systematic Reviews. - 2014. - No. 9. P. CD006647.

15. Weiss R. B. The anthracyclines: will we ever find a better doxorubicin? / R. B. Weiss // Seminars in Oncology. 1992. - Vol. 19, No. 6. - P. 670-686.

16. Geisberg C. Mechanisms of anthracycline cardiotoxicity and strategies to decrease cardiac damage / C. Geisberg, D. B. Sawyer // Current Hypertension Reports. - 2010. - Vol. 12, No. 6. - P. 404-410.

17. Mitry M. A. Doxorubicin induced heart failure: Phenotype and molecular mechanisms / M. A. Mitry, J. G. Edwards // International Journal of Cardiology. Heart \& Vasculature. - 2016. - Vol. 10. - P. 17-24.

18. Doxorubicin metabolism and toxicity in human myocardium: role of cytoplasmic deglycosidation and carbonyl reduction / S. Licata, A. Saponiero, A. Mordente [et al.] // Chemical Research in Toxicology. - 2000. - Vol. 13, No. 5. - P. 414-420.

19. Volkova M. Anthracycline cardiotoxicity: prevalence, pathogenesis and treatment / M. Volkova, R. Russell // Current Cardiology Reviews. - 2011. - Vol. 7, No. 4. - P. 214-220.

20. Doxorubicin pathways: pharmacodynamics and adverse effects / C. F. Thorn, C. Oshiro, S. Marsh [et al.] // Pharmacogenetics and Genomics. - 2011. - Vol. 21, No. 7. P. 440-446.

21. Doxorubicin cardiomyopathy / K. Chatterjee, J. Zhang, N. Honbo [et al.] // Cardiology. - 2010. - Vol. 115, No. 2. - P. 155-162.

22. Anthracycline-induced cardiotoxicity / R. Hrdina, V. Gersl, I. Klimtová [et al.] // Acta medica (Hradec Kralove). - 2000. - Vol. 43, No. 3. - P. 75-82.

23. Serum troponins as biomarkers of drug-induced cardiac toxicity / K. B. Wallace, E. Hausner, E. Herman [et al.] // Toxicologic Pathology. - 2004. - Vol. 32, No. 1. P. 106-121.

24. Ky B. Biomarker approach to the detection and cardioprotective strategies during anthracycline chemotherapy / B. Ky, J. R. Carver // Heart Failure Clinics. - 2011. Vol. 7, No. 3. - P. 323-331.

25. Serum biomarkers for the detection of cardiac toxicity after chemotherapy and radiation therapy in breast cancer patients / S. Tian, K. M. Hirshfield, S. K. Jabbour [et al.] // Frontiers in Oncology. - 2014. - Vol. 4. - P. 277.

26. Minotti G. Role of iron in anthracycline cardiotoxicity: new tunes for an old song? / G. Minotti, G. Cairo, E. Monti // The FASEB Journal. - 1999. - Vol. 13, No. 2. P. 199-212.

27. Индуцированная антрациклинами кардиотоксичность: механизмы развития и клинические проявления / М. Г. Матяш, Т. Л. Кравчук, В. В. Высоцкая [и др.] // Сибирский онкологический журнал. - 2008. T. 30, № 6. - С. 66-75.

28. Pharmacokinetic and pharmacodynamic study of doxorubicin in children with cancer: results of a "European Pediatric Oncology Off-patents Medicines Consortium" trial / M. Krischke, G. Hempel, S. Völler [et al.] // Cancer Chemotherapy and Pharmacology. -2016. - Vol. 78, No. 6. P. 1175-1184.

29. Longitudinal evaluation of early and late anthracycline cardiotoxicity in children with AML / U. Creutzig, S. Diekamp, M. Zimmermann [et al.] // Pediatric Blood \& Cancer. - 2007. - Vol. 48, No. 7. - P. 651-662.

30. Long-term cardiac sequelae in operable breast cancer patients given adjuvant chemotherapy with or without doxorubicin and breast irradiation / M. Zambetti, A. Moliterni, C. Materazzo [et al.] // Journal of Clinical Oncology. - 2001. - Vol. 19, No. 1. - P. 37-43.

31. Cardiac complications of cancer therapy: pathophysiology, identification, prevention, treatment, and future directions / D. Jain, R. R. Russell, R. G. Schwartz [et al.] / Current Cardiology Reports. - 2017. - Vol. 19, No. 5. - P. 36.

32. Изучение эффективности использования энтеросгеля в лекарственной форме пасты для перорального применения при ятрогенной интоксикации противотуберкулезными средствами / А. М. Олещук, В. В. Николаева, И. Н. Клищ [и др.] // Український журнал клінічної та лабораторної медицини. - 2009. - Т. 4, № 4. - С. 95-99.

33. Ефективність глутаргіну та ентеросгелю при ураженні печінки, викликаному протитуберкульозними препаратами / К. А. Посохова, О. О. Шевчук, А. М. Пришляк [та ін.] // Медична хімія. - 2010. - Т. 12, № 3. - С. 61-65.

34. Вивчення можливостей корекції гепатотоксичної дії антиретровірусних засобів за допомогою ентеросорбенту Ентеросгель - паста для перорального застосування. Актуальні проблеми сучасної медицини / 
Огляди літератури, оригінальні дослідження, погляд на К. А. Посохова, В. Г. Ніколаєв, О. О. Шевчук [та ін.] // Вісник Української медичної стоматологічної академії. 2010. - Т. 10, № 4. - С. 121-125.

35. Вплив ентеросгелю на стан печінки при застосуванні антиретровірусних препаратів / К. А. Посохова, В. Г. Ніколаєв, О. О. Шевчук [та ін.] // Вісник морфологiї. - 2010. - № 16 (3). - С. 548-551.

36. Посохова К. А. Корекція гепатотоксичної дії антиретровірусних засобів за допомогою глутаргіну та ентеросгелю / К. А. Посохова, О. О. Шевчук // Український журнал клінічної та лабораторної медицини. 2010. - T. 5, № 4. - С. 130-133.

37. Застосування препарату ентеросгель для профілактики оксидативного стресу при гострій крововтраті / В. Г. Ніколаєв, І. М. Кліщ, І. В. Жулкевич [та ін.] // Вісник наукових досліджень. - 2009. - № 1. - С. 72-74.

38. Грек О. Р. Протективное действие энтеросгеля на лизосомы печени крыс при введении комплекса цитостатических препаратов / О. Р. Грек, С. В. Мишенина, А. Б. Пупышев // Бюллетень экспериментальной биологии и медицины. - 2002. - Т. 134, № 10. - С. 413-417.

39. Коррекция эндотоксикоза при некоторых онкологических заболеваниях / Ю. И. Бородин, М. С. Любарский, Ю. Э. Наров [та ін.] // Бюллетень СО РАМН. 2004. - Т. 112, № 2. - С. 7-12.

40. Бонацкая Л. В. Снижение гематотоксичности противоопухолевых препаратов при энтеросорбции / Л. В. Бонацкая, В. М. Плотников, В. Г. Николаев // Экспериментальная онкология. - 1989. - Т. 23, № 11. - С. 71-73.

41. Бонацкая Л. В. Энтеросорбция как метод профилактики и лечения некоторых осложнений консервативной терапии опухолевой болезни / Л. В. Бонацкая, А. К. Зиневич // Материалы конференции "Сорбционные методы детоксикации и иммунокоррекции в медицине» (г. Харьков), 1982. - С. 4.

42. Профілактика за допомогою вуглецевого ентеросорбенту гострої та відстроченої еметогенної токсичності хіміотерапевтичного лікування онкологічних хворих / О. В. Пономарьова, В. М. Півнюк, М. М. Носко [та ін.] // Онкологія. - 2008. - Т. 10, № 3. - С. 370-373.

43. Practical recommendations on the use of granulated carbon enterosorbents "Carboline" / V. G. Nikolaev, M. A. Andreychin, K. I. Bardakhivskaya [et al.] // за ред. V. G. Nikolaev, M. A. Andreychin. - Kyiv : DIA, 2013. - 16 c.

44. Дацун А. І. Роль сорбційно-детоксикаційної та синглетно-кисневої терапії в оптимізації лікування хворих на резектабельний рак прямої кишки / А. І. Дацун // Онкология. - 2006. - Т. 8, № 4. - С. 355-358.

45. Effects of protein A immunoadsorption in patients with advanced chronic dilated cardiomyopathy / A. O. Doesch, M. Konstandin, S. Celik [et al.] // Journal of Clinical Apheresis. - 2009. - Vol. 24, No. 4. - P. 141-149.

46. Влияние препарата Реамберин на кардиотоксическое действие антрациклинов в лечении местнораспространенного рака молочной железы / Е. А. Резникова, В. К. Косенок, Г. И. Нечаева [и др.] // Вестник Санкт-Петербургской государственной медицинской академии им. И. И. Мечникова. - 2004. - № 12. С. $123-126$

47. Самура Б. Б. Повреждения миокарда, индуцированные антрациклинами. Диагностика и лечение / Б. Б. Самура // Тhегаріа. Український медичний вісник. 2008. - № 12. - C. 46-52.

48. State of the art review: Chemotherapy-induced cardiotoxicity in children / R. W. Loar, C. Noel, H. Tunuguntla [et al.] // Congenital Heart Disease. - 2018. - Vol. 13, No. 1. P. 5-15.

49. Стефанов О. В. Доклінічні дослідження лікарських засобів : методичні рекомендації / за ред. О. В. Стефанов. - К. : Авіценна, 2001. - 528 с.

50. Оськина В.В.Среднемолекулярные пептиды спинномозговой жидкости при гнойных менингитах / В. В. Оськина, К. И. Чекалина, Н. И. Габриэлян // Лаб. дело. - 1987. - № 2. - С. 23-25.

51. Габриэлян Н.И. Диагностическая ценность определения средних молекул в плазме крови при нефрологических заболеваниях / Н. И. Габриэлян, А. А. Дмитриев, Г. П. Кулаков // Клин. мед. - 1981. - № 10. - С. 38-42.

52. 30 years' follow up of randomised studies of adjuvant CMF in operable breast cancer: cohort study / G. Bonadonna, A. Moliterni, M. Zambetti [et al.] // BMJ (Clinical research ed.). - 2005. - Vol. 330, No. 7485. - P. 217.

53. Кардиоваскулярные осложнения противоопухолевой терапии / О. Ю. Голубцов, В. В. Тыренко, В.В.Лютов [и др.] // Современные проблемы науки и образования. - 2017. - № 2. - С. 126.

54. Szwajcer D. Assessment and management of febrile neutropenia in emergency departments within a regional health authority - a benchmark analysis / D. Szwajcer, P. Czaykowski, D. Turner // Current Oncology (Toronto, Ont.). - 2011. - Vol. 18, No. 6. - P. 280-284.

55. Dohle G. R. Male infertility in cancer patients: Review of the literature / G. R. Dohle // International Journal of Urology. - 2010. - Vol. 17, No. 4. - P. 327-331.

56. Advantages with prophylactic PEG-rhG-CSF versus rhG-CSF in breast cancer patients receiving multiple cycles of myelosuppressive chemotherapy: an open-label, randomized, multicenter phase III study / J. Xie, J. Cao, J. Wang [et al.] // Breast Cancer Research and Treatment. - 2018. Vol. 168, No. 2. - P. 389-399.

57. Theoretical ground for adsorptive therapy of anthracyclines cardiotoxicity / O. O. Shevchuk, E. A. Posokhova, L. A. Sakhno, [et al.] // Experimental Oncology. 2012. - Vol. 34, No. 4. - P. 314-322.

58. Nikolaev V. G. Sorption therapy with the use of activated carbons: effects on regeneration of organs and tissues / V. G. Nikolaev. - In: Hemoperfusion, plasmaperfusion and other clinical uses of general, biospecific, immuno and leucocyte adsorbents. - 2017. - P. 221-243.

59. Enterosorption in Oncotherapy / G. V. Muravskaya, V. G. Nikolaev, V. P. Sergeev [et al.] // Artificial Cells, Blood Substitutes, and Biotechnology. - 1991. - Vol. 19, No. 1. - P. 167-174. 


\section{REFERENCES}

1. Bondarenko, I.M., Zavizion, V.F., Artemenko, M.V., \& Zavizion, M.B. (2012). Mozhlyvosti udoskonalennia terapii suprovodu pry tsytostatychnomu likuvanni pukhlyn [Possibilities of improving the therapy of support in the cytostatic treatment of tumors]. Medychni Perspektyvy - Medical Perspectives, (4), 48-53 [in Ukrainian].

2. Bruslov, K.M. (2013). Zastosuvannia preparatu tevahrastym u ditei z hostrymy leikemiiamy [Use of the drug tevagrastim in children with acute leukemia]. OnkolohiiaOncology, 15 (1), 51-54 [in Ukrainian].

3. Baranova, O.Yu., \& Volkova, M.A. (2001). Vozmozhnosti sovremennoy terapii ostrykh nelimfoblastnykh leykozov vzroslykh [Possibilities of modern therapy for acute non-lymphoblastic leukemia in adults]. Russkiy meditsinskiy zhurnal. Onkologiya - Russian Medical Journal. Oncology, 9 (22), 999-1003 [in Russian].

4. Lyman, G.H., Abella, E., \& Pettengell, R. (2014). Risk factors for febrile neutropenia among patients with cancer receiving chemotherapy: A systematic review. Critical Reviews in Oncology/Hematology, 90 (3), 190-199. Retrieved from: https://doi.org/10.1016/j.critrevonc.2013.12.006

5. Liu, W., Zhang, C.-C., \& Li, K. (2013, June). Prognostic value of chemotherapy-induced leukopenia in small-cell lung cancer. Cancer Biology \& Medicine. Chinese Anti-Cancer Association. Retrieved from: https://doi.org/10.7497/j. issn.2095-3941.2013.02.005

6. Parkhill, A.L. (2013). Oral mucositis and stomatitis associated with conventional and targeted anticancer therapy. Journal of Pharmacovigilance, 01 (03). Retrieved from: https://doi.org/10.4172/2329-6887.1000112

7. Al-Ansari, S., Zecha, J.A.E.M., Barasch, A., de Lange, J., Rozema, F.R., \& Raber-Durlacher, J.E. (2015). Oral mucositis induced by anticancer therapies. Current Oral Health Reports, 2 (4), 202-211. Retrieved from: https://doi. org/10.1007/s40496-015-0069-4

8. Stensvold, E., Magelssen, H., \& Oskam, I.C. (2011). Fertility-preserving measures for girls and young women with cancer. Tidsskrift for Den Norske Lægeforening: Tidsskrift for Praktisk Medicin, Ny Række, 131 (15), 1429-1432. Retrieved from: https://doi.org/10.4045/tidsskr.11.0126

9. Diamond, O.M., Turgeman, O., \& Blumenfeld, Z. (2015). Minimizing the doxorubicin- Induced gonadotoxicity by sphingosine-1- phosphate analogue FTY720. Am. J. Clin. Exp. Obstet. Gynecol., 2 (1), 24-33.

10. Keros, V., Hultenby, K., Borgstrom, B., Fridstrom, M., Jahnukainen, K., \& Hovatta, O. (2007). Methods of cryopreservation of testicular tissue with viable spermatogonia in pre-pubertal boys undergoing gonadotoxic cancer treatment. Human Reproduction, 22 (5), 1384-1395. Retrieved from: https://doi.org/10.1093/humrep/del508

11. Kostakou, P.M., Kouris, N.T., Kostopoulos, V.S., Damaskos, D.S., \& Olympios, C.D. (2018). Cardio-oncology: a new and developing sector of research and therapy in the field of cardiology. Heart Failure Reviews, 1-10. Retrieved from: https://doi.org/10.1007/s10741-018-9731-y

12. Denduluri, N., Patt, D.A., Wang, Y., Bhor, M., Li, X., Favret, A.M., ... Lyman, G.H. (2015). Dose delays, dose reductions, and relative dose intensity in patients with cancer who received adjuvant or neoadjuvant chemotherapy in community oncology practices. JNCCN Journal of the
National Comprehensive Cancer Network, 13 (11), 1383-1393. Retrieved from: https://doi.org/10.6004/jnccn.2015.0166

13. Minotti, Giorgio, Menna, P., Salvatorelli, E., Cairo, G., \& Gianni, L. (2004). Anthracyclines: Molecular Advances and Pharmacologic Developments in Antitumor Activity and Cardiotoxicity. Pharmacological Reviews, 56 (2), 185229. Retrieved from: https://doi.org/10.1124/pr.56.2.6

14. van Dalen, E.C., Raphaël, M.F., Caron, H.N., \& Kremer, L.C. (2014). Treatment including anthracyclines versus treatment not including anthracyclines for childhood cancer. Cochrane Database of Systematic Reviews, (9), CD006647. Retrieved from: https://doi.org/10.1002/ 14651858.CD006647.pub4

15. Weiss, R.B. (1992). The anthracyclines: will we ever find a better doxorubicin? Seminars in Oncology, 19 (6), 670-686. Retrieved from: http://www.ncbi.nlm.nih. gov/pubmed/1462166

16. Geisberg, C., \& Sawyer, D.B. (2010). Mechanisms of anthracycline aardiotoxicity and strategies to decrease cardiac damage. Current Hypertension Reports, 12 (6), 404. Retrieved from: https://doi.org/10.1007/S11906-010-0146-Y

17. Mitry, M.A., \& Edwards, J.G. (2016). Doxorubicin induced heart failure: Phenotype and molecular mechanisms. International Journal of Cardiology. Heart \& Vasculature, 10, 17-24. Retrieved from: https://doi.org/10.1016/j. ijcha.2015.11.004

18. Licata, S., Saponiero, A., Mordente, A., \& Minotti, G. (2000). Doxorubicin metabolism and toxicity in human myocardium: Role of cytoplasmic deglycosidation and carbonyl reduction. Chemical Research in Toxicology, 13 (5), 414-420. Retrieved from: https://doi.org/10.1021/tx000013q

19. Volkova, M., \& Russell, R. (2011). Anthracycline cardiotoxicity: prevalence, pathogenesis and treatment. Current Cardiology Reviews, 7 (4), 214-220. Retrieved from: https://doi.org/10.2174/157340311799960645

20. Thorn, C.F., Oshiro, C., Marsh, S., Hernandez-Boussard, T., McLeod, H., Klein, T.E., \& Altman, R.B. (2011). Doxorubicin pathways: pharmacodynamics and adverse effects. Pharmacogenetics and Genomics, 21 (7), 440-446. Retrieved from: https://doi.org/10.1097/FPC.0b013e32833ffb56

21. Chatterjee, K., Zhang, J., Honbo, N., \& Karliner, J.S. (2010). Doxorubicin cardiomyopathy. Cardiology, 115 (2), 155-162. Retrieved from:https://doi.org/10.1159/000265166

22. Hrdina, R., Gersl, V., Klimtová, I., Simůnek, T., Machácková, J., \& Adamcová, M. (2000). Anthracycline-induced cardiotoxicity. Acta Medica (Hradec Kralove), 43 (3), 75-82. Retrieved from: http://www.ncbi.nlm.nih.gov/ pubmed/11089274

23. Wallace, K.B., Hausner, E., Herman, E., Holt, G.D., Macgregor, J.T., Metz, A. L., ... York, M.J. (2004). Serum troponins as biomarkers of drug-induced cardiac toxicity. Toxicologic Pathology, 32 (1), 106-121. Retrieved from: https://doi.org/10.1080/01926230490261302

24. Ky, B., \& Carver, J.R. (2011). Biomarker approach to the detection and cardioprotective strategies during anthracycline chemotherapy. Heart Failure Clinics, 7 (3), 323-331. Retrieved from: https://doi.org/10.1016/j.hfc.2011.03.002

25. Tian, S., Hirshfield, K.M., Jabbour, S.K., Toppmeyer, D., Haffty, B.G., Khan, A.J., \& Goyal, S. (2014). Serum biomarkers for the detection of cardiac toxicity after chemotherapy and radiation therapy in breast cancer patients. 
Огляди літератури, оригінальні дослідження, погляд на проблему, випадок з практики, короткі повідомлення Frontiers in Oncology, 4, 277. Retrieved from: https://doi. org/10.3389/Fonc.2014.00277

26. Minotti, G, Cairo, G., \& Monti, E. (1999). Role of iron in anthracycline cardiotoxicity: new tunes for an old song? The FASEB Journal, 13 (2), 199-212. Retrieved from: https://doi.org/10.1096/Fasebj.13.2.199

27. Matyash, M.G., Kravchuk, T.L., Vysotskaya, V.V., Chernov, V.I., \& Goldberg, V.E. (2008). Indutsirovannaya antratsiklinami kardiotoksichnost: mekhanizmy razvitiya i klinicheskiye proyavleniya [Cardiotoxicity induced by anthracyclines: developmental mechanisms and clinical manifestations]. Sibirskiy onkologicheskiy zhurnal - Siberian Oncological Journal, 30 (6), 66-75. Retrieved from: https://elibrary.ru/item.asp?id=12515758 [in Russian].

28. Krischke, M., Hempel, G., Völler, S., André, N., D'Incalci, M., Bisogno, G., ... Boos, J. (2016). Pharmacokinetic and pharmacodynamic study of doxorubicin in children with cancer: results of a "European Pediatric Oncology off-patents Medicines Consortium" trial. Cancer Chemotherapy and Pharmacology, 78 (6), 1175-1184. Retrieved from: https://doi.org/10.1007/s00280-016-3174-8

29. Creutzig, U., Diekamp, S., Zimmermann, M., \& Reinhardt, D. (2007). Longitudinal evaluation of early and late anthracycline cardiotoxicity in children with AML. Pediatric Blood \& Cancer, 48 (7), 651-662. Retrieved from: https://doi.org/10.1002/pbc.21105

30. Zambetti, M., Moliterni, A., Materazzo, C., Stefanelli, M., Cipriani, S., Valagussa, P., ... Gianni, L. (2001). Long-term cardiac sequelae in operable breast cancer patients given adjuvant chemotherapy with or without doxorubicin and breast irradiation. Journal of Clinical Oncology, 19 (1), 37-43. Retrieved from: https://doi.org/10.1200/ JCO.2001.19.1.37

31. Jain, D., Russell, R.R., Schwartz, R.G., Panjrath, G.S., \& Aronow, W. (2017). Cardiac complications of cancer therapy: Pathophysiology, identification, prevention, treatment, and future directions. Current Cardiology Reports, 19 (5), 36. Retrieved from: https://doi.org/10.1007/ s11886-017-0846-x

32. Oleshchuk, A.M., Nikolaeva, V.V., Klishch, I.N., Shevchuk, O.O., Maslenny, V.N. \& Yastremskaya, S.O. (2009). Izucheniye effektivnosti ispolzovaniya enterosgelya $v$ lekarstvennoy forme pasty dlya peroralnogo primeneniya pri yatrogennoy intoksikatsii protivotuberkuleznymi sredstvami [The study of the effectiveness of the use of enterosgel in the dosage form of an oral paste for iatrogenic intoxication with anti-TB drugs]. Ukrainskyi zhurnal klinichnoi ta laboratornoi Medytsyny - Ukrainian Journal of Clinical and Laboratory Medicine, 4 (4), 95-99 [in Russian].

33. Posokhova, K.A., Shevchuk, O.O., Prysliak, A.M., \& Mosiechuk, I.L. (2010). Efektyvnist hlutarhinu ta enteros heliu pry urazhenni pechinky, vyklykanomu protytuberkuloznymy preparatamy [Efficacy of glutargin and enterosgel in liver damage caused by anti-tuberculosis drugs]. Medychna khimiia - Medical Chemistry, 12 (3), 61-65 [in Ukrainian].

34. Posokhova, K.A., Nikolaev, V.G., Shevchuk, O.O., Oleshchuk, O.M., Klishch, I.M., \& Nikolaiev V.V. (2010). Vyvchennia mozhlyvostei korektsii hepatotoksychnoi dii antyretrovirusnykh zasobiv za dopomohoiu enterosorbentu enteros hel - pasta dlia peroralnoho zastosuvannia [Study of possibilities of correction of hepatotoxic action

of antiretroviral agents by means of enterosorbent enterosgel - paste for oral administration]. Aktualni problemy suchasnoi medytsyny. Visnyk ukrainskoi medychnoi stomatolohichnoi akademii - Topical Problems of Modern Medicine. Bulletin of the Ukrainian Medical Dental Academy, 10 (4), 121-125 [in Ukrainian].

35. Posokhova, K.A., Nikolaev, V.H., Shevchuk, O.O., Oleshchuk, O.M., Klishch, I.M., Datsko, T.V., \& Nikolaiev, V.V. (2010). Vplyv enteros·heliu na stan pechinky pry zastosuvanni antyretrovirusnykh preparativ [Effect of enterosgel on liver condition when using antiretroviral drugs]. Visnyk Morfolohii - Bulletin of Morphology, 16 (3), 548-551 [in Ukrainian].

36. Posokhova, K.A., \& Shevchuk, O.O. (2010). Korektsiia hepatotoksychnoi dii antyretrovirusnykh zasobiv za dopomohoiu hlutarhinu ta enteros heliu [Correction of hepatotoxic action of antiretroviral agents with glutargin and enterosgel]. Ukrainskyi zhurnal klinichnoi ta laboratornoi medytsyny - Ukrainian Journal of Clinical and Laboratory Medicine, 5 (4), 130-133 [in Ukrainian].

37. Nikolaiev, V.H., Klishch, I.M., Zhulkevych, I.V., Oleshchuk, O.M., Nikolaiev, V.V., \& Shevchuk, O.O. (2009). Zastosuvannia preparatu enteros hel dlia profilaktyky oksydatyvnoho stresu pry hostrii krovovtrati [The use of the drug enterosgel for the prevention of oxidative stress in acute blood loss]. Visnyk Naukovykh Doslidzhen - Bulletin of Scientific Research, (1), 72-74 [in Ukrainian].

38. Greek, O.R., Mishenina, S.V., \& Pupyshev, A.B. (2002). Protektivnoye deystviye enterosgelya na lizosomy pecheni krys pri vvedenii kompleksa tsitostaticheskikh preparatov [The protective effect of enterosgel on rat liver lysosomes with the introduction of a complex of cytostatic drugs]. Byulleten eksperimentalnoy biologii $i$ meditsiny Bulletin of Experimental Biology and Medicine, 134 (10), 413-417 [in Russian].

39. Borodin, Yu.I., Lyubarskyy, M.S., Narov, Yu.E., Morozov, V.V., \& Fursov, S.A. (2004). Korrektsiya endotoksikoza pri nekotorykh onkologicheskikh zabolevaniyakh [Correction of endotoxemia in some oncological diseases]. Byulleten SO RAMN - Bulletin SB RAMS, 112 (2), 7-12 [in Russian].

40. Bonatskaya, L.V., Plotnikov, V.M., \& Nikolaev, V.G. (1989). Snizheniye gematotoksichnosti protivoopukholevykh preparatov pri enterosorbtsii [Decreased hematotoxicity of antitumor drugs during enterosorption]. Eksperimentalnaya Onkologiya - Experimental Oncology, 23 (11), 71-73 [in Russian].

41. Bonatskaya, L.V., \& Zinevich, A.K. (1982). Enterosorbtsiya kak metod profilaktiki i lecheniya nekotorykh oslozhneniy konservativnoy terapii opukholevoy bolezni [Enterosorption as a method of prevention and treatment of some complications of conservative therapy of tumor disease]. Insorbtsionnyye metody detoksikatsii i immunokorrektsii $v$ meditsine - Insorption Methods of Detoxification and Immunocorrection in Medicine [in Russian].

42. Ponomariova, O.V., Pivniuk, V.M., Nosko, M.M., Sakhno, L.O., Dekhtiar, T.V., Nikolaiev, V.H., \& Chekhun, V.F. (2008). Profilaktyka za dopomohoiu vuhletsevoho enterosorbentu hostroi ta vidstrochenoi emetohennoi toksychnosti khimioterapevtychnoho likuvannia onkolohichnykh khvorykh [Prevention with the help of carbon enterosorbent acute and delayed emetogenic toxicity of chemo- 
Огляди літератури, оригінальні дослідження, погляд на проблему, випадок з практики, короткі повідомлення therapeutic treatment of cancer patients]. Onkolohiia Oncology, 10 (3), 370-373. Retrieved from: http://dspace. nbuv.gov.ua/handle/123456789/11944 [in Ukrainian].

43. Nikolaev, V.G., Andreychin, M.A., Bardakhivskaya, K.I., Sakhno, L.A., Kopcha, V.S., Yushko, L.A., ... Shevchuk, O.O. (2013). Practical recommendations on the use of granulated carbon enterosorbents "Carboline." Nikolaev, V.G., \& Andreychin, M.A. Eds.). Kyiv: DIA.

44. Datsun, A.I. (2006). Rol sorbtsiino-detoksykatsiinoi ta synhletno-kysnevoi terapii v optymizatsii likuvannia khvorykh na rezektabelnyi rak priamoi kyshky [The role of sorption-detoxification and singlet-oxygen therapy in optimizing the treatment of patients with resectable rectal cancer]. Onkolohiia - Oncology, 8 (4), 355-358. Retrieved from: http://dspace.nbuv.gov.ua/bitstream/handle/ 123456789/2254/11-Dacyn.pdf?sequence=1 [in Ukrainian].

45. Doesch, A.O., Konstandin, M., Celik, S., Kristen, A., Frankenstein, L., Hardt, S., ... Dengler, T.J. (2009). Effects of protein A immunoadsorption in patients with advanced chronic dilated cardiomyopathy. Journal of Clinical Apheresis, 24 (4), NA-NA. Retrieved from: https://doi.org/10.1002/ jca.20204

46. Reznikova, E.A., Kosenok, V.K., Nechaev, G.I., Merkulov, V.N., \& Reznikov, A.S. (2004). Vliyaniye preparata Reamberin na kardiotoksicheskoye deystviye antratsiklinov v lechenii mestnorasprostranennogo raka molochnoy zhelezy [The effect of Reamberin on the cardiotoxic effect of anthracyclines in the treatment of locally advanced breast cancer]. Vestnik Sankt-Peterburgskoy Gosudarstvennoy Meditsinskoy Akademii im. I. I. Mechnikova - Bulletin of Saint Petersburg State Medical Academy by I.I. Mechnikov, (12), 123-126. Retrieved from: http://as-ma.com.ua/Library/Rmb/RmbVlianie/Rmb.pdf [in Russian].

47. Samura, B.B. (2008). Povrezhdeniya miokarda, indutsirovannyye antratsiklinami. Diagnostika i lecheniye [Myocardial damage induced by anthracyclines. Diagnosis and treatment]. Terapiia. Ukrainskyi medychnyi visnyk - Therapy. Ukrainian Medical Bulletin, (12), 46-52 [in Russian].

48. Loar, R.W., Noel, C., Tunuguntla, H., Colquitt, J.L., \& Pignatelli, R.H. (2018). State of the art review: Chemotherapy-induced cardiotoxicity in children. Congenital Heart Disease, 13(1), 5-15. Retrieved from: https://doi.org/10.1111/chd.12564

49. Stefanov, O.V. (Ed.). (2001). Doklinichni doslidzhennia likarskykh zasobiv: metodychni rekomendatsii [Preclinical drug research: guidelines]. Kyiv: Avitsenna. Retrieved from: https://www.twirpx.com/file/537410/ [in Ukrainian].

50. Oskina, V.V., Chekalina, K.I., \& Gabrielyan, N.I. (1987). Srednemolekulyarnyye peptidy spinnomozgovoy zhidkosti pri gnoynykh meningitakh [Medium molecular peptides of cerebrospinal fluid in purulent meningitis]. Lab. Delo-Lab. Case, (2), 23-25 [in Russian].

51. Gabrielyan, N.I., Dmitriev, A.A., \& Kulakov, G.P. (1981). Diagnosticheskaya tsennost opredeleniya srednikh molekul v plazme krovi pri nefrologicheskikh zabolevaniyakh [The diagnostic value of determining the average molecules in the blood plasma with nephrological diseases]. Klin. Med. - Clinical Medicine, (10), 38-42 [in Russian].

52. Bonadonna, G., Moliterni, A., Zambetti, M., Daidone, M. G., Pilotti, S., Gianni, L., \& Valagussa, P. (2005). 30 years' follow up of randomised studies of adjuvant CMF in operable breast cancer: cohort study. BMJ (Clinical Research Ed.), 330 (7485), 217. Retrieved from: https://doi.org/10.1136/ bmj.38314.622095.8F

53. Golubtsov, O.Yu., Tyrenko, V.V., Lyutov, V.V., Maslyakov, V.V., \& Makiev, R.G. (2017). Kardiovaskulyarnyye oslozhneniya protivoopukholevoy terapii. [Cardiovascular complications of antitumor therapy]. Sovremennyye problemy nauki i obrazovaniya - Modern Problems of Science and Education, (2). Retrieved from https://www.science-education.ru/pdf/2017/2/26380.pdf [in Russian].

54. Szwajcer, D., Czaykowski, P., \& Turner, D. (2011). Assessment and management of febrile neutropenia in emergency departments within a regional health authority-a benchmark analysis. Current Oncology (Toronto, Ont.), 18 (6), 280-284. Retrieved from: http://www.ncbi.nlm.nih.gov/ pubmed/22184489.

55. Dohle, G.R. (2010). Male infertility in cancer patients: Review of the literature. International Journal of Urology, 17 (4), 327-331. Retrieved from: https://doi. org/10.1111/j.1442-2042.2010.02484.x

56. Xie, J., Cao, J., Wang, J., Zhang, B., Zeng, X., Zheng, H., ... Hu, X. (2018). Advantages with prophylactic PEG-rhG-CSF versus rhG-CSF in breast cancer patients receiving multiple cycles of myelosuppressive chemotherapy: an open-label, randomized, multicenter phase III study. Breast Cancer Research and Treatment, 168 (2), 389-399. Retrieved from: https://doi.org/10.1007/s10549-017-4609-6

57. Shevchuk, O.O., Posokhova, E.A., Sakhno, L.A., \& Nikolaev, V.G. (2012). Theoretical ground for adsorptive therapy of anthracyclines cardiotoxicity. Experimental Oncology, 34 (4), 314-322.

58. Nikolaev, V.G. (2017). Sorption therapy with the use of activated carbons: Effects on regeneration of organs and tissues. In hemoperfusion, plasmaperfusion and other clinical uses of general, biospecific, immuno and leucocyte adsorbents. Retrieved from: https://doi.org/10.1142/ 9789814749084_0007

59. Muravskaya, G.V., Nikolaev, V.G., Sergeev, V.P., Krutilina, N.I., Bonatskaya, L.V., Klevtsov, V. N., ... Sinajko, V.V. (1991). Enterosorption in oncotherapy. artificial cells. Blood Substitutes, and Biotechnology, 19 (1), 167-174. Retrieved from: https://doi.org/10.3109/10731199109117823 
Огляди літератури, оригінальні дослідження, погляд на проблему, випадок з практики, короткі повідомлення ЭФФЕКТЫ ЭНТЕРОСОРБЦИИ И ФИЛГРАСТИМА ПРИ СУБХРОНИЧЕСКОЙ ДОКСОРУБИЦИНОВОЙ ТОКСИЧНОСТИ

○О. О. Шевчук

\author{
Тернопольский национальный медицинский университет имени И. Я. Горбачевского Мз Украины
}

РЕЗЮМЕ. Побочные реакции при проведении противоопухолевой химиотерапии часто стают причиной приостановки лечения.

Цель работы - изучить влияние энтеросорбента С2 и препарата гранулоцитарного колониестимулирующего фактора (Г-КСФ) на гематологические параметры и биохимические показатели функционирования сердца, почек, печени у крыс на модели субхронической доксорубициновой токсичности.

Материал и методы. Субхроническую токсичность моделировали введением доксорубицина (DOX) интраперитонеально 1 раз в неделю в дозе 5 мг/кг масы крысы четырёхкратно. Для коррекции использовали углеродный гранулированный энтеросорбент С2 и филграстим. На 29 сутки после первой инъекции DOX изучали основные гематологические параметры, активность ферментов КФК-МВ, АлАТ, АсАТ, лужной фосфатазы, уровень общего белка, церулоплазмина, креатинина и мочевины, концентрацию $\mathrm{MCM}_{1}$ и $\mathrm{MCM}_{2}$.

Результаты. На фоне субхронической доксорубициновой токсичности ухудшаются гематологические параметры исследуемых животных, нарушаются белково-синтетическая функция печени и показатели функционирования почек, о чем свидетельствует повышение уровней мочевины и креатинина на 26,2 и 19,2 \%. Все эти процессы сопровождаются выраженным увеличением маркеров эндогенной интоксикации $\mathrm{MCM}_{1}$ в 2 раза, МСМ 2 - в 1,75 раза. На кардиотоксичность DOX указывает достоверное увеличение активности АсАТ и КФК-МB - маркеров повреждения сердечной мышцы (на 75,1 и 64,2 \% соответственно).

Применение энтеральной сорбционной терапии уменьшает побочные эффекты доксорубицина, что проявляется улучшением гематологических параметров, функции почек, уменьшением показателей эндогенной интоксикации. Однако, именно комбинация энтеросорбента С2 с препаратом Г-КСФ демонстрирует более существенное улучшение исследуемых показателей, особенно маркеров повреждения миокарда: уменьшилась активность ферментов АсАТ на 26,3 \%, КФК-МВ - на 17,0 \%; АлАТ - на 20,4 \%.

Выводы. Полученные нами результаты служат основой для дальнейшего исследования применения энтеросорбции и Г-КСФ для уменьшения побочных реакций антрациклиновых антибиотиков и их внедрения в Клиническую практику.

КЛЮЧЕВЫЕ СЛОВА: энтеросорбция; доксорубицин; филграстим; крысы.

\title{
EFFECTS OF ENTEROSORPTION AND FILGRASTIM IN SUBCHRONIC DOXORUBICIN TOXICITY
}

๑O. O. Shevchuk

\section{Horbachevsky Ternopil National Medical University}

SUMMARY. Side effects of antineoplastic drugs frequently are the main factor for interrupting of tumoricidal therapy.

The aim - to study effects of enterosorbent C2 and granulocyte colony stimulating factor (G-CSF) on hematological parameters and biochemical tests of heart, kidney and liver functions in subchronic doxorubicin toxicity.

Material and Methods. Subchronic toxicity was modelled injecting doxorubicin (DOX) intraperitoneally once a week at the dose of $5 \mathrm{mg} / \mathrm{kg} 4$ times. We used oral carbon adsorbent C2 and filgrastim for correction. On 29th day after first injection of DOX hematological parameters, activity of creatine phosphokinase-MB (CPK-MB), ALT, AST, alkaline phosphatase, levels of total protein, ceruloplasmin, creatinine, urea, $\mathrm{MSM}_{1}$ and $\mathrm{MSM}_{2}$ were tested.

Results. Hematological parameters, synthetic function of the liver and kidney function indicators were decreased in subchronic doxorubicin toxicity with raised levels of urea and creatinine by 26.2 and $19.2 \%$. Level of markers of endogenous intoxication were elevated MSM $_{1}$ by 2 times, MSM $_{2}$ - by 1.75 times. Cardiotoxic influences of DOX is confirmed by significant increasing of enzymes' activity AST and CPK-MB by 75.1 and $64.2 \%$, which are the markers of heart damage.

Enterosorption ameliorates side effects of subchronic doxorubicin toxicity. We observed improvements of hematological parameters, kidney's function and decrease of endogenous intoxication markers. But the combination of enterosorbent C2 and G-CSF demonstrates more significant enhancement of tests, especially activity of AST by $26.3 \%$, CPK-MB by - by $17.0 \%$; ALT - by $20.4 \%$.

Conclusions. Our results substantiated deeper study of efficiency of enterosorption and G-CSF to ameliorate side effects of anthracyclines and its implementation into clinics.

KEY WORDS: enterosorption; doxorubicin; filgrastim, rats. 